\title{
Association of the bovine growth hormone gene with Holstein cattle reproductive parameters
}

\section{Asociación del gen de la hormona de crecimiento bovino con parámetros reproductivos en ganado Holstein}

\author{
Juliana Arango G,* M.Sc, Julián Echeverri Z, Ph.D, Albeiro López H, Ph.D.
}

Universidad Nacional de Colombia, Facultad de Ciencias Agropecuarias, Departamento de Producción Animal, Grupo BIOGEM, Sede Medellín, AA 1779, Colombia. *Correspondencia: jarangog@unal.edu.co.

Received: November 2013; Accepted: March 2014.

\begin{abstract}
Objective. To determine the association of intron 3 polymorphism of the bovine growth hormone (BGH) gene, with age at first service, first birth, first postpartum service and second birth in a population of Holstein cows in the state of Antioquia. Materials and methods. The study was conducted on 408 Holstein cows in 8 herds. Genotyping was performed using PCR-RFLP technique with DNA extracted from peripheral blood by the salting out technique. The Phenotypic information used was collected for 4 years, from a dairy production control program. To determine the association between characteristics and gene polymorphism, parametric statistical analyzes were performed as generalized linear models and linear regression analysis. Results. Allele frequency (positive) was 0.91 and was 0.09 for (negative) allele. Genotypic frequencies were $0.77,0.2$ and 0.03 for (positive/positive), (positive/negative) and (negative/negative) respectively. There were significant differences between the mean of age at first service, age at first birth, age at first postpartum service and age at second birth. For all of the (negative/negative) genotype characteristics there were greater ages for each event. Conclusions. These results suggest that intron-3 polymorphism of the BGH gene is associated with reproductive traits, facilitating the selection of individuals with favorable genotypes for use in breeding programs.
\end{abstract}

Key words: Animal reproduction, molecular markers, PCR-RFLP (Source: Mesh).

\section{RESUMEN}

Objetivo. Determinar la asociación del polimorfismo del intrón 3 del gen de la hormona de crecimiento bovino $(B G H)$ con las edades al primer servicio, primer parto, primer servicio posparto y segundo parto en una población de vacas Holstein del departamento de Antioquia. Materiales y métodos. El estudio se realizó con 408 vacas Holstein ubicadas en 8 hatos. La genotipificación se llevó a cabo usando la técnica de PCR-RFLP con ADN extraído de sangre periférica mediante la técnica de salting out. La información fenotípica utilizada fue recopilada durante 4 años, a partir de un programa de control de producción lechera. Para determinar la asociación entre las características y el polimorfismo del gen, se realizaron análisis estadísticos paramétricos mediante modelos lineales generalizados y análisis de regresión lineal. Resultados. La frecuencia para el alelo (positivo) fue de 0.91 y para el alelo (negativo) fue de 0.09 . Las frecuencias genotípicas fueron $0.77,0.2$ y 0.03 para (positivo/ positivo), (positivo/negativo) y (negativo/negativo) respectivamente. Se presentaron diferencias 
significativas entre las medias de la edad al primer servicio, la edad al primer parto, edad al primer servicio postparto y edad al segundo parto. Para todas las características el genotipo (negativo/ negativo) presentó edades más tardías para cada eventos. Conclusiones. Estos resultados sugieren que el polimorfismo del intrón 3 del gen BGH, está asociado con características de tipo reproductivo, facilitando la implementación de un programa de selección de individuos con genotipos favorables, para su uso en programas de mejoramiento genético animal.

Palabras clave: Marcadores moleculares, PCR-RFLP, reproducción animal (Fuente: Mesh).

\section{INTRODUCTION}

In specialized dairy herds, reproductive efficiency has a direct influence on productivity. Without efficient reproductive performance, milk production is strongly affected and thus the profitability of the herd. Cow fertility is affected by many factors, the age of the animal at puberty has a very strong influence and is transcendental due to the fact that older ages at the start of breeding and first calving reflect low reproductive efficiency (1).

A delay in the age of service or birth of each cow, or even, each cow discarded as a result of infertility affects the economic performance of the herd. When a heifer is delayed in entering the breeding program or a cow delays in returning to heat after delivery, there are expenses for the additional non-lactating period and lengthening of the generational interval $(1,2)$. In contrast, reduction of the heifers' rearing period and rapid growth, which brings them to the reproductive stage in a shorter amount of time, produces more births and more production during their lifetime. Therefore, it is essential to consider the factors that influence these parameters. The bovine growth hormone $(\mathrm{BGH})$ gene has polymorphisms that influence these characteristics differently (2) and play a key role in the regulation of growth and development; indirectly influencing the reproductive efficiency of cattle (3-7).

BGH effect on growth is observed in several tissues including bone, muscle and adipose tissue. These effects result from both direct action of BGH on nutrient partitioning and on cell multiplication, as in the action mediated by the insulin-like growth factor 1 , which stimulates cell proliferation and metabolic processes associated with protein deposition (8). In addition, significant relationships have been reported between $\mathrm{BGH}$ concentrations and the postpartum period, and consequently with cow fertility (9.10).

The main concern behind the analysis of this association is to determine the influence of genetic variants of growth hormone on the scope of an earlier active reproductive stage. The aim

\section{INTRODUCCIÓN}

En los hatos lecheros especializados, la eficiencia reproductiva tiene una influencia directa sobre la productividad. Sin un desempeño reproductivo eficiente, la producción de leche es afectada fuertemente y por tanto, la rentabilidad económica del hato. La fertilidad de la vaca se encuentra afectada por muchos factores, la edad a la pubertad del animal tiene una influencia muy fuerte $y$ es trascendental debido a que las edades elevadas al inicio de la reproducción y al primer parto se reflejan en una baja eficiencia reproductiva (1).

El retraso en la edad de servicio o parto de cada vaca, o aun, cada vaca descartada por infertilidad, afecta el rendimiento económico del hato. Cuando una novilla se demora en entrar al programa reproductivo o una vaca se demora en retornar al celo después del parto, se generan gastos por el período adicional no lactante y el alargamiento del intervalo generacional $(1,2)$. En contraste, la reducción del período de levante de las novillas y un crecimiento rápido, que las acerque en menor tiempo a la etapa reproductiva, produce como resultado más partos y más producción durante su vida. Por tanto es esencial considerar los factores que influyen sobre el conjunto de estos parámetros. El gen de la hormona del crecimiento bovino (BGH) presenta polimorfismos que influyen de manera diferente estas características (2) y juegan un papel clave en la regulación del crecimiento y el desarrollo; influyendo de forma indirecta la eficiencia reproductiva del bovino (3-7).

Los efectos de la BGH sobre el crecimiento se observan en varios tejidos, incluyendo huesos, músculos y tejido adiposo. Estos efectos resultan tanto de la acción directa de la BGH en la partición de nutrientes y en la multiplicación celular, como en la acción mediada por el factor de crecimiento insulinoide tipo 1 , que estimula la proliferación celular y los procesos metabólicos, asociados a la deposición de proteínas (8). Además, se han reportado relaciones significativas entre las concentraciones de $\mathrm{BGH}$, con el período postparto y consecuentemente con la fertilidad de la vaca $(9,10)$. 
of the research was to determine the association of intron 3 polymorphism of the bovine growth hormone $(\mathrm{BGH})$ gene, with ages at first service, first birth, first postpartum service and second birth, in a population of Holstein cows in the state of Antioquia.

\section{MATERIALS AND METHODS}

Study areas and population. 408 Holstein cattle were used, belonging to 8 dairy herds located in the high tropics of Antioquia, northern and eastern areas of the state, in the municipalities of San Pedro de los Milagros (height 2475 mamsl; with a temperature of $14^{\circ} \mathrm{C}$, Belmira (height 2550 mamsl, $\mathrm{T}^{\circ} 14^{\circ} \mathrm{C}$ ) and Santa Elena township of Medellín (height 2500 mamsl, $\mathrm{T}^{\circ} 17^{\circ} \mathrm{C}$ ).

DNA extraction and determination of genotypic variants. To determine the genotypic variants, coccygeal vein blood was extracted and DNA extraction was performed using the salting out technique (11). Only genomic DNA with suitable purity between $1.8-2.0$ was considered for the studies to be performed.

The following oligonucleotides were synthesized, of 20 base pairs (pb) F 5'CCC ACG GGC AAG AAT GAG GC 3', R5' TGA GGA ACT GCA GGG GCC CA 3', which enabled amplification of the $329 \mathrm{bp}$ fragment which has the restriction site for endonuclease MspI (12).

This was carried out by PCR amplification for the specific region, using a final volume of $25 \mu \mathrm{l}$ containing $2.5 \mu \mathrm{l}$ 10X PCR buffer (1.0-1.5 mM of $\mathrm{MgCl}_{2}, 50 \mathrm{mM}$ of KCl, $10 \mathrm{mM}$ of Tris- $\mathrm{HCl}, \mathrm{pH}$ of 8.3), $0.2 \mu \mathrm{M}$ of primers; $0.4 \mathrm{mM}$ of each dNTPs, $2 \mathrm{mM}$ of $\mathrm{MgCl}_{2} 1$ unit of Taq polymerase and $\sim 30-60 \mathrm{ng}$ of genomi DNA.

PCR was performed in a thermocycler (Biometra ${ }^{\circledR}$ ). The conditions for amplification of the specific region of the $\mathrm{BGH}$ gene were: initial denaturation with heating for five minutes at $94^{\circ} \mathrm{C}$, followed by 39 cycles of denaturation at $94^{\circ} \mathrm{C}$ for 1 minute, primer alignment (anneling) at $55^{\circ} \mathrm{C}$ for 1 minute, extension at $72^{\circ} \mathrm{C}$ for $1 \mathrm{~min}$, and a final extension step of 3 minutes at $72^{\circ} \mathrm{C}$ to complete the reaction (12). The annealing temperature used was determined by following the recommendation of the primer supplier and through different trials that yielded more efficient alignment to said temperature $\left(55^{\circ} \mathrm{C}\right)(12)$. As a positive control for all reactions, amplification of samples that were previously evaluated was performed and as negative control reactions in the absence of DNA. Genotypic variants were determined by using RFLP (Restriction Fragment Length Polymorphism), using the
El interés principal del análisis de esta asociación, viene dado por la determinación de la influencia de las variantes genéticas de la hormona del crecimiento sobre el alcance de un estado reproductivo activo más temprano. El objetivo de la investigación fue determinar la asociación del polimorfismo del intrón 3 del gen de la hormona de crecimiento bovino $(\mathrm{BGH})$, con las edades al primer servicio, primer parto, primer servicio posparto y segundo parto en una población de vacas Holstein del departamento de Antioquia.

\section{MATERIALES Y MÉTODOS}

Áreas y población en estudio. Se utilizaron 408 bovinos de la raza Holstein pertenecientes a 8 hatos lecheros ubicados en el trópico alto Antioqueño, zonas norte y oriental del departamento, en los municipios de San Pedro de los Milagros (altura 2475 msnm; con una temperatura $\left(\mathrm{T}^{\circ}\right)$ de $14^{\circ} \mathrm{C}$ ), Belmira (altura 2550 msnm; $T^{\circ} 1^{\circ} \mathrm{C}$ ) y Medellín corregimiento Santa Elena (altura $2500 \mathrm{msnm}$; $\mathrm{TO}^{\circ} \mathrm{17}^{\circ} \mathrm{C}$ ).

Extracción de ADN y determinación de las variantes genotípicas. Para la determinación de las variantes genotípicas, se extrajo sangre de la vena coccígea y se realizó la extracción del ADN, mediante la técnica de salting out (11). Sólo el ADN genómico con una pureza adecuada entre 1.8-2.0 se consideró para los estudios a realizar.

Se sintetizaron los siguientes oligonucleótidos, de 20 pares de bases $(\mathrm{pb}) \mathrm{F} 5^{\prime}$ CCC ACG GGC AAG AAT GAG GC 3', R 5' TGA GGA ACT GCA GGG GCC CA 3', que permitieron amplificar el fragmento de 329 pb que presenta el sitio de restricción para la endonucleasa MspI (12).

Se llevó a cabo una amplificación mediante PCR para la región específica, usando un volumen final de $25 \mu$ que contenía $2.5 \mu$ tampón PCR 10X (1.0-1.5 mM de $\mathrm{MgCl}_{2}, 50 \mathrm{mM}$ de $\mathrm{KCl}, 10 \mathrm{mM}$ de Tris- $\mathrm{HCl}, \mathrm{pH}$ de 8.3), $0.2 \mu \mathrm{M}$ de cebadores; 0.4 $\mathrm{mM}$ de cada dNTPs, $2 \mathrm{mM}$ de $\mathrm{MgCl}_{2}, 1$ unidad de Taq polimerasa y 30-60 ng de ADN genómico.

La PCR se realizó en un termociclador (Biometra ${ }^{\circledR}$ ). Las condiciones para la amplificación de la región específica del gen BGH fueron: la desnaturalización con calentamiento inicial durante cinco minutos a $94^{\circ} \mathrm{C}$, seguido por 39 ciclos de desnaturalización a $94^{\circ} \mathrm{C}$ por 1 minuto, alineamiento de cebadores (anneling) a $55^{\circ} \mathrm{C}$ por 1 minuto, extensión a $72^{\circ} \mathrm{C}$ por 1 min y un paso de extensión final de 3 minutos a $72{ }^{\circ} \mathrm{C}$ para terminar la reacción (12). La temperatura de alineamiento utilizada se determinó siguiendo la recomendación de los distribuidores de los cebadores y mediante diferentes ensayos que arrojaron mayor eficiencia de alineamiento a la temperatura citada $\left(55^{\circ} \mathrm{C}\right),(12)$. Como control positivo de todas las 
restriction enzyme MspI. A final volume of $20 \mu \mathrm{l}$ was used, containing $5 \mu \mathrm{l}$ of PCR product, $2 \mu \mathrm{l}$ of buffer Tango $1 \mathrm{X}, 12.5 \mu$ of ultra-pure water, which was subjected to digestion by 5 units of restriction enzyme MspI for three hours at $37^{\circ} \mathrm{C}$. The resulting product was observed by electrophoresis in agarose gel at $2.5 \%(\mathrm{w} / \mathrm{v})$ and ethidium bromide staining. The restriction pattern expected for the (negative/negative) genotype was a $329 \mathrm{pb}$ fragment, for the (positive/negative) genotype three fragments (329, 224 and $105 \mathrm{pb}$ ) and for the (positive/ positive) genotype two fragments (224 and $105 \mathrm{pb})$.

Estimation of allele frequencies. The frequency of the different alleles was estimated by determining the proportion of each form of the gene among the total number of copies in the study population. Homozygotes (two copies of the same allele) and heterozygous (one copy of each allele) were identified, and the frequency (F) of each allele was calculated by counting homozygotes and adding half the heterozygotes, with the method described by Hartl (13).

Statistical Analysis. To determine the association of each characteristic with the genotype for the $\mathrm{BGH}$, several generalized linear models were adjusted based on known sources of variation for each of the dependent variables (age at first service, age at first birth, age at first postpartum service and age at second birth). The Tukey analysis was used to determine differences between the means for each of the fixed effect levels included in the models. The statistical packet SAS v9.2 was used for all analyzes (SAS Inst Inc., Cary, NC), (14).

The general model of fixed effects was carried out as follows:

$$
\begin{aligned}
Y_{i j k m n o p q}=\mu & +G_{i}+H_{j}+A N_{k}+M N_{1}+(M N * A N)_{m}+\left(H^{*} A N\right)_{n} \\
& +\left(H^{*} M N\right)_{0}+\left(H^{*} M N * A N\right)_{p}+\left(H^{*} G\right)_{q}+e_{j k k l m n o p q}
\end{aligned}
$$$$
\text { Where: }
$$

$Y_{i j k \mid m n o p q}=$ age at first service, age at first birth, age at first postpartum service or age at second birth, of individual $X$, carrier of genotype i, located in herd $j$, with year of birth $k$ and month of birth I

$\mu=$ mean for the characteristic

$\mathrm{G}_{\mathrm{i}}=$ fixed effect of the gentoype for $\mathrm{BGH}(\mathrm{i}=1 \ldots 3)$

$H_{j}=$ fixed effect of the herd $(j=1 \ldots 8)$

$A N_{k}=$ fixed effect of the year of birth $(k=1 \ldots 15)$

$M N_{1}=$ fixed effect of the month of birth $(I=1 \ldots 12)$

$(M N * A N)_{m}=$ fixed effect of the interaction between the month of birth and the year of birth $(\mathrm{m}=1 \ldots 86)$

$\left(H^{*} A N\right)_{n}=$ fixed effect of the interaction between reacciones se realizó la amplificación de muestras que fueron previamente evaluadas, y como control negativo reacciones en ausencia de ADN. Las variantes genotípicas fueron determinadas mediante la utilización de RFLP (Restriction Fragment Lenght Polymorphism), usando la enzima de restricción MspI. Se usó un volumen final de $20 \mu l$ que contenía $5 \mu \mathrm{l}$ del producto de PCR, $2 \mu \mathrm{l}$ de tampón Tango $1 \mathrm{X}, 12.5 \mu \mathrm{l}$ de agua ultra pura, los cuales fueron sometidos a digestión por 5 unidades de enzima de restricción MspI durante tres horas a $37^{\circ} \mathrm{C}$. El producto resultante se observó por electroforesis en gel de agarosa al $2.5 \%(\mathrm{p} / \mathrm{v})$ y tinción con bromuro de etidio. El patrón de restricción esperado para el genotipo (negativo/negativo) fue un fragmento de $329 \mathrm{pb}$, para el genotipo (positivo/negativo) tres fragmentos $(329,224$ y $105 \mathrm{pb}$ ) y para el genotipo (positivo/positivo) dos fragmentos (224 pb y $105 \mathrm{pb}$ ).

Estimación de las frecuencias alélicas. La frecuencia de los diferentes alelos se estimó determinando la proporción de cada forma del gen entre el número de copias totales de la población en estudio. Se identificaron los homocigotos (dos copias del mismo alelo) y los heterocigotos (una copia de cada alelo), y se calculó la frecuencia (F) de cada alelo contando los homocigotos y añadiendo la mitad de los heterocigotos, con el método descrito por Hartl (13).

Análisis estadístico. Para determinar la asociación de cada una de las características con el genotipo para BGH, se llevó a cabo el ajuste de varios modelos lineales generalizados, basados en las fuentes de variación conocidas para cada una de las variables dependientes (edad al primer servicio, edad al primer parto, edad al primer servicio postparto y edad al segundo parto). El análisis de medias de Tukey fue utilizado para determinar las diferencias entre las medias para cada uno de los niveles de los efectos fijos incluidos en los modelos. Se utilizó el paquete estadístico SAS v9.2., para todos los análisis (SAS Inst. Inc., Cary, NC), (14).

El modelo general de efectos fijos llevado a cabo fue el siguiente:

$\begin{aligned} Y_{i j k m n o p q}= & \mu+G_{i}+H_{j}+A N_{k}+M N_{1}+(M N * A N)_{m}+\left(H^{*} A N\right)_{n} \\ & +\left(H^{*} M N\right)_{O}+\left(H^{*} M N * A N\right)_{p}+\left(H^{*} G\right)_{q}+e_{j k k m n o p q}\end{aligned}$ Dónde:

$\mathrm{Y}_{\mathrm{ijklmnopq}}=$ edad al primer servicio, edad al primer parto, edad al primer servicio postparto o edad al segundo parto, del individuo $X$, portador del genotipo $i$, ubicado en el hato $j$, con año de nacimiento $\mathrm{k}$ y mes de nacimiento $\mathrm{I}$

$\mu=$ media para la característica

$\mathrm{G}_{\mathrm{i}}=$ efecto fijo del Genotipo para BGH $(\mathrm{i}=1 \ldots 3)$

$H_{j}=$ efecto fijo del hato $(j=1 \ldots 8)$

$A N_{k}=$ efecto fijo del Año de Nacimiento $(k=1 \ldots 15)$ 
the herd and the year of birth $(n=1 \ldots 46)$ $\left(H^{*} M N\right)_{0}=$ fixed effect of the interaction between the herd and the month of birth $(0=1 \ldots 68)$

$\left(\mathrm{H}^{*} \mathrm{MN} * \mathrm{AN}\right)_{\mathrm{P}}=$ fixed effect of the interaction between the herd, the month of birth and the year of birth $(p=1 \ldots 41)$

$\left(H^{*} \mathrm{G}\right)_{\mathrm{q}}=$ fixed effect of the interaction between the herd and the genotype $(q=1 \ldots .13)$

$\mathrm{e}_{\mathrm{ijk} \mid \mathrm{mnopq}}=$ experimental error.

An analysis of simple linear regression was conducted to determine the effect of allelic substitution on each of the study variables. For this, the genotype was converted to a quantitative scale 0,1 and 2 for (negative/negative), (positive/ negative) and (positive/positive), respectively.

The linear regression model used was the following:

$Y_{i}=\beta_{0}+\beta_{1} X_{i}+e_{i}$

Where:

$Y_{i}=\quad$ value of the dependent variable (age at first service, age at first birth, age at first postpartum service and age at second birth) depending on the number of + alleles

$\beta_{0}=$ intercept

$\beta_{1}=$ coefficient of linear regression estimated for allele replacement $(+)$

$X_{i}=$ number of + alleles in individual $i .(0,1,2)$

$\mathrm{e}_{\mathrm{i}}=$ experimental error.

\section{RESULTS}

Determination of genotype and allele frequencies of the gene for the growth hormone (BGH). A $329 \mathrm{pb}$ fragment was amplified from the DNA of 408 animals. The analysis of the restriction fragments using the MspI enzyme originated two restriction patterns; $329 \mathrm{pb}$, corresponding to the (negative) allele and 224 and $105 \mathrm{pb}$, corresponding to the (positive) allele. Allele frequencies (positive) and (negative) were 0.91 and 0.09 , respectively. The genotype frequencies were $0.77,0.2$ and 0.03 for (positive/positive), (positive/negative) and (negative/negative), respectively.

Descriptive analysis. The average age at first service was $589 \pm 91.17$ days. For the age at first birth an average of $911 \pm 126.2$ days was obtained, for the first postpartum service $1013 \pm 142.57$ days, and for the second birth $1314 \pm 138.01$ days was obtained. All characteristics showed a relatively low Coefficient of Variation (CV), with the age at first service having the highest value (15.4\%) (Table 1). However, these values are too
$M N=$ efecto fijo del mes de Nacimiento $(I=1 \ldots 12)$ $(M N * A N)_{m}=$ efecto fijo de la interacción entre el mes de nacimiento y el año de nacimiento $(m=1 \ldots 86)$

$\left(H^{*} A N\right)_{n}=$ efecto fijo de la interacción entre el hato y el año de nacimiento $(n=1 . .46)$

$\left(H^{*} M N\right)_{0}=$ efecto fijo de la interacción entre el hato y el mes de nacimiento $(0=1 \ldots 68)$

$(H * M N * A N)_{\mathrm{P}}=$ efecto fijo de la interacción entre el hato, el mes de nacimiento y el año de nacimiento $(p=1 \ldots 41)$

$\left(H^{*} \mathrm{G}\right)_{\mathrm{a}}=$ efecto fijo de la interacción entre el hato $y$ el genotipo $(q=1 \ldots .13)$

$\mathrm{e}_{\mathrm{ijklmnopq}}=$ error experimental.

Se realizó un análisis de regresión lineal simple, para determinar el efecto de sustitución alélica con cada una de las variables en estudio. Para este fin, el genotipo se convirtió a una escala cuantitativa 0,1 y 2 para (negativo/ negativo), (positivo/negativo) y (positivo/ positivo), respectivamente.

El modelo de regresión lineal utilizado fue el siguiente:

$Y_{i}=\beta_{0}+\beta_{1} X_{i}+e_{i}$

Dónde:

$\mathrm{Y}_{\mathrm{i}}=\quad$ valor de la variable dependiente (edad al primer servicio, edad al primer parto, edad al primer servicio postparto y edad al segundo parto) en función del número de alelos +

$\beta_{0}=$ intercepto

$\beta_{1}=$ coeficiente de regresión lineal estimado para

el alelo de sustitución $(+)$

$\mathrm{X}_{\mathrm{i}}=$ número de alelos + en el individuo i. $(0,1,2)$

$e_{i}=$ error experimental.

\section{RESULTADOS}

Determinación de las frecuencias alélicas y genotípicas del gen de la hormona de crecimiento (BGH). Se amplificó un fragmento de 329 pb a partir del ADN de 408 animales. El análisis de los fragmentos de restricción usando la enzima MspI, originó 2 patrones de restricción; $329 \mathrm{pb}$, correspondiente al alelo (negativo) y 224 y $105 \mathrm{pb}$, correspondiente al alelo (positivo). Las frecuencias alélicas de (positivo) y (negativo) fueron de 0.91 y 0.09 , respectivamente. Las frecuencias genotípicas fueron $0.77,0.2$ y 0.03 para (positivo/positivo), (positivo/negativo) y (negativo/negativo), respectivamente.

Análisis descriptivo. El promedio para la edad al primer servicio fue de $589 \pm 91.17$ días. Para la edad al primer parto se obtuvo un promedio de 
high with respect to the reproductive goals that efficient milk production systems should have (1). Descriptive statistics for all characteristics are summarized in table 1 .

Table1. Mean, standard deviation (SD) and coefficient of variation (CV) for the age at first service, age at first birth, age at first postpartum service and age at second birth in Holstein cows in the state of Antioquia.

\begin{tabular}{lcccc}
\hline \multicolumn{1}{c}{ Characteristic } & N & Mean & SD & CV\% \\
\hline Age at first service (days) & 433 & 589 & 91.1 & 15.4 \\
Age at first birth (days) & 448 & 911 & 126.2 & 13.8 \\
Age at first postpartum service (days) & 391 & 1013 & 142.5 & 14.0 \\
Age at second birth (days) & 453 & 1314 & 138.0 & 10.5 \\
\hline
\end{tabular}

Effect of genotype on the age of reproductive events. The genotype had a highly significant effect $(p \leq 0.01)$ on age at first service; the model showed a coefficient of determination of 0.88 ; indicating that the herd, year of birth, month of birth, interaction between the month and year of birth, between the herd and year of birth, herd and month of birth, and interaction between the herd, month and year of birth, explained an $88 \%$ variation of the characteristic. The Tukey analysis, which was performed subsequently, showed that heifers with the (negative/negative) genotype took 69 days more for their first service than heifers with the (positive/positive) genotype. Likewise, (positive/negative) individuals were delayed 13 days more than (positive/positive) individuals. Animals with the (negative/negative) genotype had a lower performance because they had their first service at later ages. These results are presented in table 2 .

The genotype had a highly significant effect $(p \leq 0.01)$ on age at first birth and first postpartum service; the model showed a coefficient of determination of 0.81 and 0.83 respectively, indicating that the effects included in the model explained the $81 \%$ variation in age at first birth and $83 \%$ variation in age at first postpartum
$911 \pm 126.2$ días, para el primer servicio postparto de $1013 \pm 142.57$ días y para el segundo parto de $1314 \pm 138.01$ días. Todas las características mostraron unos Coeficientes de Variación (CV) relativamente bajos, siendo la edad al primer servicio la que presentó el valor más elevado (15.4\%) (Tabla 1). Sin embargo, estos valores son demasiado elevados con respecto a las metas reproductivas que deberían de tener los sistemas de producción lechera eficientes (1). En la tabla 1 se resume la estadística descriptiva para todas las características.

Efecto del genotipo sobre las edades de los eventos reproductivos. El genotipo tuvo un efecto altamente significativo $(p<0.01)$ sobre la edad al primer servicio; el modelo presentó un coeficiente de determinación de 0.88 ; indicando que el hato, el año de nacimiento, mes de nacimiento, la interacción entre el mes y año de nacimiento, entre el hato y año de nacimiento, hato y mes de nacimiento y la interacción entre el hato el mes y el año de nacimiento, explicaron en un $88 \%$ la variación de la característica. El análisis de medias de Tukey, que se realizó posteriormente, mostró como las novillas con genotipo (negativo/negativo) tardaron 69 días más para su primer servicio que las novillas con genotipo (positivo/positivo). De la misma forma, los individuos (positivo/negativo) se demoraron 13 días más que las (positivo/positivo). Los animales con genotipo (negativo/negativo) presentaron un menor rendimiento, ya que tuvieron su primer servicio a edades más tardías Estos resultados son presentados en la tabla 2.

El genotipo tuvo un efecto altamente significativo $(p<0.01)$ sobre la edad al primer parto y al primer servicio postparto; el modelo presentó un coeficiente de determinación de 0.81 y 0.83 respectivamente, indicando que los efectos incluidos en el modelo explicaron en el $81 \%$ la variación en la edad al primer parto y en el $83 \%$ la variación en la edad al primer servicio postparto. El análisis de medias de Tukey, llevado a cabo posteriormente, mostró diferencias significativas $(p<0.05)$, denotando al genotipo (negativo/negativo) como el menos

Table 2. Tukey analysis for age at first service, first birth, first postpartum service and second birth in Holstein cows in the state of Antioquia.

\begin{tabular}{cccc}
\hline Genotype & Age at first service (days) & $\begin{array}{c}\text { Age at frst birth } \\
\text { (days) }\end{array}$ & $\begin{array}{c}\text { Age at first postpartum } \\
\text { service (days) }\end{array}$ \\
\hline (positive/positive) & $577.4^{\mathrm{a}}$ & $905.0^{\mathrm{a}}$ & $998.2^{\mathrm{a}}$ \\
(positive/negative) & $590.3^{\mathrm{b}}$ & $905.3^{\mathrm{a}}$ & $1304.6^{\mathrm{a}}$ \\
(days) & $1000.1^{\mathrm{a}}$ & $1305.8^{\mathrm{a}}$ \\
(negative/negative) & $646.3^{\mathrm{c}}$ & $967.3^{\mathrm{b}}$ & $1040.4^{\mathrm{b}}$ \\
\hline
\end{tabular}

Different letters in the same column indicate significant differences. 
service. The Tukey analysis, subsequently carried out, showed significant differences ( $p \leq 0.05)$, denoting the (negative/negative) genotype as the least favorable, as it showed the later age for both characteristics. The analysis of means for the (positive/positive) and (positive/negative) genotypes showed no significant differences ( $p>0.05$, Table 2).

The genotype had a highly significant effect $(p \leq 0.01)$ on age at second birth; the model showed a coefficient of determination of 0.79 , indicating that the effects included in the model explained the $79 \%$ variation of this characteristic. The Tukey analysis showed significant differences ( $p \leq 0.05$ ) among the means, denoting the (negative/negative) genotype as the least favorable for age at second birth, with an average of more days. The analysis of means of the (positive/positive) and (negative/positive) genotypes showed no significant differences ( $p>0.05$, Table 2).

Effect of allelic replacement of BGH gene polymorphism on the ages at which some reproductive events occur. For the age at first service, a regression coefficient $(\beta)$ of -20.3 was found, indicating that for each (positive) allele that the individual bears, the age at first service decreases by 20 days; age at first birth had a regression coefficient $(\beta)$ of -11.67 , ie, for each (positive) allele, the age at first birth decreases by 11 days. For the age at first postpartum service the $\beta$ coefficient was -8.5 , indicating that for each (positive) allele, the age decreases by 8 days, and the $\beta$ for the age at second birth was -15.83 indicating that for each (positive) allele, the age at second birth decreases by 15 days. Regression coefficients for each of the characteristics are shown in table 3.

The estimated regression coefficients for age at first and second birth were highly significant $(p<0.01)$. The regression coefficient for age at first birth was significant $(p<0.05)$. For age at first postpartum service, the regression coefficient was not statistically significant $(p>0.05)$.

Table 3. Regression Analysis for characteristics: age at first service, first birth, first postpartum service and second birth.

\begin{tabular}{lccc}
\hline \multicolumn{1}{c}{ Characteristic } & Intercept (I) & Beta $(\boldsymbol{\beta})$ & $\begin{array}{c}\text { Standard } \\
\text { Error } \boldsymbol{\beta}\end{array}$ \\
\hline $\begin{array}{l}\text { Age at first service (days) } \\
(p<0.01)\end{array}$ & 617.21 & -20.3 & 3.09 \\
$\begin{array}{l}\text { Age at first birth (days) } \\
(p<0.01)\end{array}$ & 927.37 & -11.67 & 4.4 \\
$\begin{array}{l}\text { Age at first postpartum service } \\
\text { (days) }\end{array}$ & 1015.05 & -8.5 & 4.9 \\
$\begin{array}{l}(p<0.05) \\
\begin{array}{l}\text { Age at second birth (days) } \\
(p>0.05)\end{array}\end{array}$ & 1335.04 & -15.83 & 5.2 \\
\hline
\end{tabular}

favorable, pues mostraba la edad más tardía para ambas características. El análisis de medias de los genotipos (positivo/positivo) y (positivo/ negativo) no mostró diferencias significativas ( $p>0.05$, Tabla 2).

El genotipo tuvo un efecto altamente significativo $(p<0.01)$ sobre la edad al segundo parto; el modelo mostró un coeficiente de determinación de 0.79 , indicando que los efectos incluidos en el modelo explicaron en el $79 \%$ la variación de esta característica. El análisis de medias de Tukey mostró diferencias significativas $(p<0.05)$ entre las medias, denotando al genotipo (negativo/ negativo) como el menos favorable para la edad al segundo parto, con un promedio de días mayor. El análisis de medias de los genotipos (positivo/ positivo) y (negativo/positivo) no mostraron diferencias significativas ( $p>0.05$, Tabla 2$)$.

Efecto de sustitución alélica del polimorfismo
del gen BGH sobre las edades a las cuales se
presentan algunos eventos reproductivos. Para la edad al primer servicio se encontró un coeficiente de regresión $(\beta)$ de -20.3 , indicando que por cada alelo (positivo) que porte el individuo, la edad al primer servicio disminuye en 20 días; la edad al primer parto tuvo un coeficiente de regresión $(\beta)$ de -11.67 , es decir, por cada alelo (positivo) la edad al primer parto disminuye en 11 días. Para la edad al primer servicio postparto el coeficiente $\beta$ fue de -8.5 , indicando que por cada alelo (positivo) la edad disminuye en 8 días, y el $\beta$ para la edad al segundo parto fue de -15.83 indicando que por cada alelo (positivo) la edad al segundo parto disminuye en 15 días. Los coeficientes de regresión para cada una de las características son mostrados en la tabla 3.

Los coeficientes de regresión estimados para la edad al primer servicio y segundo parto, fueron altamente significativos $(p<0.01)$. El coeficiente de regresión para la edad al primer parto fue significativo $(p<0.05)$ y para la edad al primer servicio postparto no fue estadísticamente significativo $(p>0.05)$.

\section{DISCUSIóN}

Las frecuencias genotípicas y alélicas obtenidas en el presente trabajo coinciden con las reportadas por Gorbani et al (15), quienes en una población de 183 animales de raza Holstein, encontraron frecuencias de $0.787,0.191$ y 0.022 para los genotipos (positivo/positivo), (positivo/negativo) y (negativo/negativo) respectivamente, y 0.883 y 0.117 para los alelos (positivo) y (negativo) respectivamente. 


\section{DISCUSSION}

Genotypic and allelic frequencies obtained in this study agree with those reported by Gorbani et al (15), who, in a population of 183 Holsteins, found frequencies of $0.787,0.191$ and 0.022 for (positive/positive), (positive/negative) and (negative/negative) genotypes, respectively, and 0.883 and 0.117 for (positive) and (negative) alleles respectively.

Mullen et al (16) found an association between three of six polymorphisms located in the first exon ( $5^{\prime}$ region) of the GH gene. These newly found SNP were associated with pregnancy rate and first service; however, no association with the age at which the event occurs were performed. Reports generated by Katalin et al (17) mentioned that polymorphism recognized by the AluI enzyme in the exon 5 region position 127, and designated $L$ and $\mathrm{V}$ alleles, is not associated with the age at first birth in Holstein cows.

The age at first breeding in heifers is an important parameter of reproductive efficiency; reducing the rearing period and rapid entry to the breeding program generates a higher economic return; a later age, the result obtained in this research, reflects low reproductive efficiency in the herd (1.2).

The age at first birth is another important factor in the productive life of the animal. Advanced ages at which this event occurs impact lesser milk production and increased feed intake, resulting, therefore, in a higher initial cost of breeding (18). Establishing the age around which heifers are giving birth evaluates the growth rate from birth to the time they contribute milk or calves to the system and return the rearing investment. The age at first birth in this study was also high and therefore should be the subject of work by both farmers and researchers.

The (negative/negative) genotype was less favorable, as it delays the age at first service, as well as the age at first birth, postpartum service and second birth. Although the low frequency of the (negative/negative) genotype may indicate some limitation when performing association analysis, the intron 3 polymorphism of the BGH showed significant results for all characteristics.

The greatest effect of genotype polymorphism of the BGH was on age at first service. For each (positive) allele, the first service occurred 20 days before. This effect decreased age at first birth by 11 days and for age at second birth by 15 days. The decrease in each of these parameters is important for the herd's breeding performance, resulting in
Mullen et al (16), encontraron asociación entre tres de seis polimorfismos, situados en el primer exón (región 5 ') del gen GH. Estos nuevos SNP encontrados, se asociaron con la tasa de preñez al primer servicio; sin embargo, no se realizaron asociaciones con la edad a la cual ocurre dicho evento. Reportes generados por Katalin et al (17) mencionan que el polimorfismo reconocido por la enzima AluI de la región del exón 5 posición 127, y con alelos designados $L$ y $V$, no están asociados con la edad al primer parto en vacas Holstein.

La edad al primer servicio en las novillas es un importante parámetro de eficiencia reproductiva; la reducción del periodo de levante y una entrada rápida al programa de reproducción genera mayor rendimiento económico; una edad tardía, resultado obtenido en esta investigación, refleja una baja eficiencia reproductiva en el hato $(1,2)$.

La edad al primer parto es otro factor importante en la vida productiva del animal. Edades avanzadas en las que ocurre este evento repercuten en una menor producción láctea y en un mayor consumo de alimento, derivando, por tanto, en un mayor costo inicial de crianza (18). Establecer la edad alrededor de la cual las novillas están pariendo evalúa la velocidad de crecimiento desde el nacimiento hasta el momento en que pueden aportar leche o terneros al sistema para retornar la inversión de su levante. La edad al primer parto en este estudio fue también alta y por ende, debería ser materia de trabajo por parte de los productores e investigadores.

El genotipo (negativo/negativo) fue el menos favorable, pues retrasa la edad al primer servicio, así como también la edad al primer parto, al servicio postparto y al segundo parto. Aunque la baja frecuencia del genotipo (negativo/ negativo), puede significar una cierta limitación al realizar análisis de asociación, el polimorfismo del intrón 3 de la BGH mostró resultados significativos para todas las características.

El mayor efecto del genotipo del polimorfismo de la BGH se presentó sobre la edad al primer servicio. Por cada alelo (positivo), el primer servicio se presentó 20 días antes. Este efecto disminuyó en la edad al primer parto en 11 días y para la edad al segundo parto en 15 días. La disminución en cada uno de estos parámetros es importante en el desempeño reproductivo del hato, dando como resultado una vida útil productiva más prolongada (19, 20). Es así como la asociación del polimorfismo de la BHG puede utilizarse como ayuda para seleccionar animales que tiendan a entrar a 
a longer productive life $(19,20)$. Thus, association of BHG polymorphism can be used to help select animals that tend to enter reproductive stages earlier, decreasing economic losses generated in the breeding of animals to maturity (21).

The finding that the positive/positive genotype influences the age at first service, reducing the rearing period, may indicate a lower age at second birth and increased productive life of these carrier animals. Early entry to breeding programs generates greater economic performance and lower feed intake which results in lower breeding costs. This information, in productive and reproductive terms, is an important contribution to breeding programs (1).

In conclusion this is a pioneering study on the association of intron 3 polymorphisms of the BGH with reproductive characteristics of dairy cows. The results suggest that the intron 3 polymorphism of the BGH is associated with age at first service, first birth, first postpartum service and second birth by facilitating the selection of individuals with favorable genotypes for use in breeding programs.

We found that the positive/positive genotype is optimal for reducing age at first service, first birth, first postpartum service and second birth; the genotype's greatest effect being on age at first service.

Due to the low frequency of the negative/ negative genotype; increasing the sample size is recommended for future studies and to achieve greater reliability in the results. etapas reproductivas tempranas disminuyendo pérdidas económicas que se generan en la cría de los animales hasta la madurez (21).

El hallazgo de que el genotipo positivo/positivo tiene influencia sobre la edad al primer servicio repercute en la reducción del periodo de levante, lo que podría indicar menor edad al segundo parto y una mayor vida productiva de estos animales portadores. La entrada temprana a los programas de reproducción genera mayor rendimiento económico y menor consumo de alimento que se deriva en un menor costo de crianza, por lo que esta información, en términos productivos y reproductivos, es un aporte importante para los programas de selección (1).

En conclusión este es un estudio pionero en la asociación de los polimorfismos del intrón 3 del gen $\mathrm{BGH}$ con características reproductivas en vacas lecheras. Los resultados sugieren que el polimorfismo del intrón 3 de la BGH está asociado con las edades al primer servicio, primer parto, primer servicio posparto y segundo parto facilitando la selección de individuos con genotipos favorables para su utilización en programas de mejoramiento genético.

Se encontró que el genotipo positivo/positivo es el óptimo para la disminución de la edad al primer servicio, primer parto, primer servicio postparto y segundo parto; teniendo el genotipo mayor efecto en la edad al primer servicio.

Debido a la baja frecuencia del genotipo negativo/ negativo; se recomienda aumentar el tamaño de la muestra para futuros estudios y conseguir mayor confiabilidad en los resultados.

\section{REFERENCES}

1. Faure R, Morales C. La pubertad de la hembra bovina: I. aspectos fisiológicos. Rev Salud Anim 2003; 25(1):13-19.

2. Zhou G, Jin H, Liu C, Guo S, Zhu Q, Wu Y. Association of genetic polymorphism in $\mathrm{GH}$ gene with milk production traits in Beijing Holstein cows. J Biosci 2005; 30(5):595-598.

3. Abolfazl G, Rasoul T, Mortaza B, Cyrus A. Restriction fragment length polymorphism of bovine growth hormone gene intron 3 and its association with testis biometry traits in Iranian Holstein bull. Afr J Microbiol Res 2009;3(11):809-814.
4. Kanoth K, Kouno S, Okazaki A, Suzuki K, Obara Y. Interaction of GH polymorphism with body weight and endocrine functions in Japanese black calves. Domest Anim Endocrinol 2008;34(1):25-30.

5. Pereira A, Maurício M, Henrique N, Luciana C. Association of GH and IGF-1 polymorphisms with growth traits in a synthetic beef cattle breed. Genet Mol Biol 2005; 28(2):230-236.

6. Curi A, Oliveira N, Silveira C, Lopes R. Association between IGF-I, IGF-IR and GHRH gene polymorphisms and growth and carcass traits in beef cattle. Livest Prod Sci 2005; 94(3):159-167. 
7. Kanoth K, Kouno S, Okazaki A, Suzuki K, Obara Y. Interaction of $\mathrm{GH}$ polymorphism with body weight and endocrine functions in Japanese black calves. Domest Anim Endocrinol 2008; 34(1):25-30.

8. An P, Hou J, Wang I, Li G, Wang J, Song Y. Polymorphisms of the growth hormone gene and their effect on growth traits in Chinese goats. Meat Sci 2010; 86(3):758-763.

9. Patton J, Kenny D, Mcnamara S, Mee J, O'mara F, Diskin M, et al. Relationships among milk production, energy balance, plasma analytes, and reproduction in Holstein-Friesian cows. J Dairy Sci 2007; 90(2):649-658.

10. Lucy M. Functional differences in the growth hormone and insulin-like growth factor axis in cattle and pigs: implications for post-partum nutrition and reproduction. Reprod Domest Anim 2008; 43(2):31-39.

11. Rodríguez N, López A, Echeverri J. Estructura genética poblacional del gen lactoferrina bovino en vacas Holstein del departamento de Antioquia. Rev MVZ Córdoba 2013; 18(1):3355-3361.

12. Dybus A. Associations of growth $(\mathrm{GH})$ and Prolactin (PRL) genes polymorphisms with milk production traits in Polish Black and White cattle. Anim Sci P 2002; 20(4):203-212.

13. Hartl DL, and Clark AG. Principles of population genetics. 4th edition Sunderland (MA): Sinauer Associates Inc Publishers 2007.

14. SAS 9.2 SQL. Statistical Analysis Systems Institute., Inc., Cary, N.C, USA, 2009.
15. Gorbani A, Vaez T, Bonyadi M, Amirinia C. A MspI PCR-RFLP within bovin growth hormone gene and its association with sperm quality traits in Iranian Holstein bulls. Afr J Biotechnol 2009; 8(19);4811-4816.

16. Mullen $P$, Lynch $C$, Waters $S$, Howard D, O'boyle P, Kenny D, et al. Single nucleotide polymorphisms in the growth hormone and insulin-like growth factor-1 genes are associated with milk production, body condition score and fertility traits in dairy cows. Genet Mol Res 2011; 10(3):1819-1830.

17. Katalin $\mathrm{K}$, József $\mathrm{V}$, Attila Z, István G, László $\mathrm{F}$. Associations between the AluI polymorphism of growth hormone gene and production and reproduction traits in a Hungarian HolsteinFriesian bull dam population. Arch Tierz 2006; 49(3):236-249.

18. Orrego J, Alfredo D, Echavarría L. Vida productiva y principales causas de descartes de vacas Holstein en la cuenca de lima. Rev int vet Perú 2003; 14(1):68-73.

19. Haworth G, Tranter W, Chuck J, Cheng Z, Wathes $V$. Relatioships between age at first calving and first lactation milk yield, and lifetime productivity and longevity in dairy cows. Vet Rec 2008; 162(20):643-647.

20. Marini P. Comportamiento de vacas de diferentes edades al primer parto. Arch Zootec 2004; 53(202):205-208.

21. Arauna $P$, Chakravarty $A$, Bhattacharya $T$, Joshi B, Arjava S. Detection of Polymorphism of Growth Hormone Gene for the Analysis of Relationship between Allele Type and Growth Traits in Karan Fries Cattle. J Anim Sci 2004; 17(10):1334-1337. 